\title{
Scoliogeny of adolescent idiopathic scoliosis: inviting contributions for a discussion based on evidence and theoretical interpretations aiming ultimately to prevention or aetiological treatment
}

\author{
R Geoffrey Burwell ${ }^{1 *}$, Peter H Dangerfield ${ }^{2,3,4}$ and Theodoros B Grivas ${ }^{5}$
}

This Editorial initiates a Thematic Series on the aetiology, pathogenesis and pathomechanisms (scoliogeny) of adolescent idiopathic scoliosis (AIS). It introduces the Series and invites contributions from researchers in the field and from interested parties. The aim is to develop a wideranging online discussion based on evidence and theoretical interpretations, In doing this, it will extend the role of the electronic focus group of the International Federated Body on Scoliosis Etiology (IBSE) which discussed nine selected topics from 2003 to 2013 [1,2].

While the relationship between scoliosis and growth was recognized forty years ago [3], progress in understanding the causation of AIS was fettered by a relative paucity of basic biological and biomechanical scientific data. Since then and subsequent to emphasis in pathogenesis on sagittal spinal plane [4] and relative anterior spinal overgrowth [5], advances in biological knowledge have enabled scoliogenic understanding to progress particularly after the year 2000 [6-8]. Knowledge limtation still restricts scoliogenic understanding for example in relation to the biochemistry and endocrinology of AIS [9] and the abnormal extra-spinal skeletal length asymmetries of AIS girls which are of unknown pathogenetic significance $[2,10,11]$. Research on the genetic variant hypothesis of disease for AIS has led to significant achievements [12]. Within the research forum of the British Scoliosis Research Foundation [13] there is a separate, private forum for the International Scoliosis Genetics Interest Group (ISGIG), a specialist group formed at the 2011 International Phillip Zorab Symposium. A possible role for environmental and epigenetic factors in AIS scoliogeny is

\footnotetext{
* Correspondence: gburwell@tiscali.co.uk

${ }^{1}$ Centre for Spinal Studies and Surgery, Nottingham University Hospitals Trust, Queen's Medical Centre Campus, Derby Road, Nottingham NG7 2UH, UK

Full list of author information is available at the end of the article
}

uncertain [14]. The application of 3-D biomechanical methods to the trunk [15], simulation by finite element analysis [16], and biomechanical evaluation of the vicious circle hypothesis [17] are all important developments. While a neurobiological [10] and neuromuscular [18] basis for AIS scoliogeny is supported by increasing evidence, systemic metabolic abnormalities have been revealed [19-21] suggesting whole organism involvement [22] and leading to a blood test for idiopathic scoliosis [23].

Relatively less explored in scoliogenic research is how the unique combination of human form, function, size, shape, growth patterns and laterality acquired during evolution distinguishing it from other species of primate may predispose humans, but not other primates, to AIS. There is a clear need for this research as evolutionary science can be viewed as the fundamental 'organizing principle' of all biology [24]. Some human physical modes and the underlying genetic and physiological controls that may predisose to AIS include, upright posture with bipedalism, spinal rotations and counter-rotations during gait [25], asymmetry of the normal spine [26], ribcage $[1,27,28]$, upper arms [11], and handedness [29,30], prolonged period of the human growth curve and adolescent spurt [31], neuro-osseous timing of growth and maturation $[8,32,33]$, and the breaking of bilateral symmetry [34]. In experimental animals, quadrupedal or rendered bipedal [35], scoliogeny is widely studied, but the question often remains, how much applies to humans?

This Series begins with a summary of presentations during 2012 selected from two international scoliosis meetings, the International Research Society of Spinal Deformities in Poznan, Poland, and the Scoliosis Research Society in Chicago, USA [36]. This summary of the presentations reveals the diversity of current scoliogenic research, theory, and the lack of a unifying hypothesis. The latter may result from AIS being not one disease but final 
common pathways expressed in the trunk resulting from abnormalities in different causal paths which may interact and with mechanical factors.

Where does this leave the treatment of AIS? At present, such scoliogenic research does not add to the weaponry of treatment which limits its appeal to the pragmatic mind. There is hope that novel non-surgical preventive treatments other than braces [37] may be discovered, targeting the appropriate aetiology, and/or aetiopathogenetic pathways, to avoid surgery and maintain spinal mobility. Prevention of curve progression, if not curve initiation, by early diagnosis and treatment is the aim of research into the scoliogeny of AIS.

\section{Competing interests}

None of the authors has any competing interests in relation to the concepts discussed in this article.

\section{Authors' contributions}

The idea for a Thematic Series on the aetiology of AIS was initiated by TG. The text of this Editorial was written largely by GB after discussion with PD and TG. The title was formulated by TG. All authors read and approved the final manuscript.

\section{Author details}

${ }^{1}$ Centre for Spinal Studies and Surgery, Nottingham University Hospitals Trust, Queen's Medical Centre Campus, Derby Road, Nottingham NG7 2UH, UK. ${ }^{2}$ University of Liverpool, Ashton Street, Liverpool L69 3GE, UK. ${ }^{3}$ Staffordshire University, Leek Road, Stoke-on-Trent ST4 2DF, UK. ${ }^{4}$ Royal Liverpool Children's Hospital, Eaton Road, Liverpool L12 2AP, UK.

${ }^{5}$ Department of Trauma and Orthopedics, "Tzanio" General Hospital, Tzani and Afendouli 1 st, Piraeus 18536, Greece.

Received: 26 April 2013 Accepted: 26 April 2013

Published: 10 May 2013

\section{References}

1. Sevastik J, Burwell RG, Dangerfield PH: A new concept for the etiopathogenesis of the thoracospinal deformity of idiopathic scoliosis: summary of an electronic focus group debate of the IBSE. Eur Spine J 2003, 12:440-450.

2. Grivas TB, Burwell RG, Dangerfield PH: Body mass index in relation to truncal asymmetry of healthy adolescents, a physiopathogenetic concept in common withidiopathic scoliosis. Summary of an electronic focus group debate of the IBSE. Scoliosis. in press.

3. Burwell RG: The relationship between scoliosis and growth. In Scoliosis and Growh, Proceedings of a Third Symposium. Edited by Zorab PA. Edinburgh and London: Churchill Livingstone; 1971:131-150.

4. Millner PA, Dickson RA: Idiopathic scoliosis: biomechanics and biology. Eur Spine J 1996, 5(6):362-373.

5. Guo X, Chau W-W, Chan YL, Cheng J-C-Y, Burwell RG, Dangerfield PH: Relative anterior spinal overgrowth in adolescent idiopathic scoliosis result of disproportionate endochondral-membranous bone growth? Summary of an electronic focus group debate of the IBSE. Eur Spine J 2005, 14:862-873.

6. Lowe TG, Edgar M, Margulies JY, Miller NH, Raso VJ, Reinker KA, Rivard C-H: Current concepts review: etiology of idiopathic scoliosis: current trends in research. J Bone Joint Surg Am 2000, 82-A:1157-1168.

7. Burwell RG, Dangerfield PH: Etiology of Adolescent Idiopathic Scoliosis: Current Trends and Relevance to New Treatment Approaches. In State of the Art Reviews: Spine. Edited by Burwell RG, Dangerfield PH, Lowe TG, Margulies JY. Philadelphia: Hanley \& Belfus Inc; 2000. 14(2): i-xviii \& 299-520.

8. Burwell RG: Biology is the future of scoliosis treatment. Stud Health Technol Inform 2002, 88:309-315.

9. Lombardi G, Akoume MY, Colombini A, Moreau A, Banfi G: Biochemistry of adolescent idiopathic scoliosis. Adv Clin Chem 2011, 54:165-182.
10. Wang WJ, Yeung HY, Chu WC, Tang NL, Lee KM, Qiu Y, Burwell RG, Cheng JC: Top theories for the etiopathogenesis of adolescent idiopathic scoliosis. J Pediatr Orthop 2011, 31:S14-S27.

11. Burwell RG, Aujla RK, Grevitt MP, Randell TL, Dangerfield PH, Cole AA, Kirby AS, Polak FJ, Pratt RK, Webb JK, Moulton A: Upper arm length model suggest transient bilateral asymmetry is associated with right thoracic adolescent idiopathic scoliosis (RT-AIS) with implications for pathogenesis and estimation of linear growth. Stud Health Technol Inform 2012, 176:188-194.

12. Wise CA, Gao X, Shoemaker S, Gordon D, Herring JA: Understanding genetic factors in idiopathic scoliosis, a complex disease of childhood. Curr Genomics 2008, 9(1):51-59.

13. International Scoliosis Genetics Interest Group: (accessed April 2013) BSRF Research Forum.

14. Burwell RG, Dangerfield PH, Moulton A, Grivas TB: Adolescent idiopathic scoliosis (AIS), environment, exposome and epigenetics: a molecular perspective of postnatal normal spinal growth and the etiopathogenesis of AIS with consideration of a network approach and possible implications for medical therapy. Scoliosis 2011, 6(1):26. doi:10.1186/1748-7161-6-26.

15. Beauchamp A, Dansereaux J, de Guise J, Labelle H: Computer assisted digitization system for scoliotic spinal radiographs. In International Symposium on 3-D scoliotic deformities. Edited by Dansereau J. Gustav Fischer Verlag, Stuttgart, Germany: International Symposium on 3-D Scoliotic Deformities joined with the VIlth International Symposium on Spinal Deformity and Surface Topography. Ėdition de l'École Polytechnique de Montrēal; 1992:18-25.

16. Shi L, Wang D, Driscoll M, Villemure I, Chu WC, Cheng JC, Aubin CE: Biomechanical analysis and modeling of different vertebral growth patterns in adolescent idiopathic scoliosis and healthy subjects. Scoliosis 2011, 6:11. doi:10.1186/1748-7161-6-11.

17. Stokes IAF, Burwell RG, Dangerfield PH: Biomechanical spinal growth modulation and progressive adolescent scoliosis - a test of the 'vicious cycle' pathogenetic hypothesis: Summary of an electronic focus group debate of the IBSE. Scoliosis 2006, 1. 16 7161-1-16.

18. Wapstra FH, Veldhuizen AG: Hypothesis on the pathogenesis of idiopathic scoliosis, Chapter 1. In Recent Advances in Scoliosis. Edited by Grivas TB. Intech, Rijeka, Croatia; 2012:3-22.

19. Lowe TG, Burwell RG, Dangerfield PH: Platelet calmodulin levels in adolescent idiopathic scoliosis: can they predict curve progression and severity? Summary of an electronic focus group debate of the IBSE. Eur Spine J 2004, 13:257-265.

20. Moreau A, Wang DS, Forget S, Azeddine B, Angeloni D, Fraschini F, Labelle H, Poitras B, Rivard C-H, Grimard G: Melatonin signaling dysfunction in adolescent idiopathic scoliosis. Spine 2004, 29(16):1772-1781.

21. Acaroglu E, Bobe R, Enouf J, Marcucio R, Moldovan F, Moreau A: The metabolic basis of adolescent idiopathic scoliosis: 2011 report of the "metabolic" workgroup of the Fondation Yves Cotrel. Eur Spine J 2012 21(6):1033-42.

22. Burwell RG, Dangerfield PH: Whither the etiopathogenesis (and scoliogeny) of adolescent idiopathic scoliosis? Stud Health Technol Inform 2012, 176:3-19.

23. Moreau A, Akoumé Ndong MY, Azeddine B, Franco A, Rompré PH, RoyGagnon MH, Turgeon I, Wang D, Bagnall KM, Poitras B, Labelle H, Rivard CH, Grimard G, Ouellet J, Parent S, Moldovan F: Molecular and genetic aspects of idiopathic scoliosis. Blood test for idiopathic scoliosis. Orthopade 2009, 38(2):114-6. doi:10.1007/s00132-008-1362-x (Article in German). 118-21.

24. Gluckman P, Beedle A, Hanson M: Preface to Principles of Evolutionary Medicine. Oxford University Press; 2009:xiii-xvi.

25. Burwell RG, Cole AA, Cook TA, Grivas TB, Kiel AW, Moulton A, Thirlwall AS, Upadhyay SS, Webb JK, Wemyss-Holden SA, Whitwell DJ, Wojcik AS, Wythers DJ: Pathogenesis of idiopathic scoliosis. The Nottingham concept. Acta Orthop Belg 1992, 58(Suppl 1):33-58.

26. Castelein RM: Pre-existent rotation of the normal spine at different ages and its consequences for the scoliotic mechanism. Stud Health Technol Inform 2012, 176:20-5

27. Grivas TB, Burwell RG, Purdue M, Webb JK, Moulton A: A segmental analysis of thoracic shape in chest radiographs of children. Changes related to spinal level, age, sex, side and significance for lung growth and scoliosis. J Anat 1991, 78:21-38.

28. Grivas TB, Burwell RG, Purdue M, Webb JK, Moulton A: The segmental patterns of rib-vertebra angles in chest radiographs of children. Changes 
related to rib level, age, sex, side and significance for scoliosis. Clin Anat 1992, 5:272-288.

29. Grivas TB, Vasiliadis ES, Polyzois VD, Mouzakis V: Trunk asymmetry and handedness in 8245 school children. Pediatr Rehabil 2006, 9(3):259-66. doi:10.1080/10428190500343027.

30. Goldberg CJ, Moore DP, Fogarty EE, Dowling FE: Handedness and spinal deformity. Stud Health Technol Inform 2006, 123:442-8.

31. Bogin B: The evolution of human growth. Chapter 3. In Patterns of human growth. Secondth edition. Cambridge University Press; 1999:98-152.

32. Chu WCW, Lam WWM, Ng BKW, Lam T-p, Lee K-m, Guo X, Cheng JCY, Burwell RG, Dangerfield PH, Jaspan T: Relative shortening and functional tethering of spinal cord in adolescent scoliosis - Result of asynchronous neuro-osseous growth? Summary of an electronic focus group debate of the IBSE. Scoliosis 2008, 3:8. doi:10.1186/1748-7161-3-8.

33. Burwell RG, Aujla RK, Grevitt MP, Dangerfield PH, Moulton A, Randell TL, Anderson SI: Pathogenesis of adolescent idiopathic scoliosis in girls - a double neuro-osseous theory involving disharmony between two nervous systems, somatic and autonomic expressed in the spine and trunk: possible dependency on sympathetic nervous system and hormones with implications for medical therapy. Scoliosis 2009, 4:24. doi:10.1186/1748-7161-4-24.

34. Burwell RG, Dangerfield PH, Freeman BJ, Aujla RK, Cole AA, Kirby AS, Pratt RK, Webb JK, Moulton A: Etiologic theories of idiopathic scoliosis: the breaking of bilateral symmetry in relation to left-right asymmetry of internal organs, right thoracic adolescent idiopathic scoliosis (AIS) and vertebrate evolution. Stud Health Technol Inform 2006, 123:385-90.

35. Machida M, Dubousset J, Yamada T, Kimura J, Saito M, Shiraishi T, Yamagishi M: Experimental scoliosis in melatonin-deficient C57BL/6J mice without pinealectomy. J Pineal Res 2006, 1(1):1-7.

36. Burwell RG, Dangerfield PH, Moulton A, Grivas TB, Cheng JCY: Whither the etiopathogenesis (and scoliogeny) of adolescent idiopathic scoliosis? Incorporating presentations on scoliogeny at the 2012 IRSSD and SRS Meetings. Scoliosis 2013, 8:4. doi:10.1186/1748-7161-8-4.

37. Grivas TB: Maintaining mobility of the spine..., Steps toward more effective scoliosis brace treatment to prevent the need for fusion. Bone and Joint J. http://www.boneandjoint.org.uk/content/maintaining-mobilityspine\%E2\%80\%A6 entitled.

doi:10.1186/1748-7161-8-8

Cite this article as: Burwell et al: Scoliogeny of adolescent idiopathic scoliosis: inviting contributions for a discussion based on evidence and theoretical interpretations aiming ultimately to prevention or aetiological treatment. Scoliosis 2013 8:8.

\section{Submit your next manuscript to BioMed Central and take full advantage of:}

- Convenient online submission

- Thorough peer review

- No space constraints or color figure charges

- Immediate publication on acceptance

- Inclusion in PubMed, CAS, Scopus and Google Scholar

- Research which is freely available for redistribution 